\title{
Relasi Enviromental Typography, Public Space dan Gaya Hidup
}

\section{Dodi Nursaiman}

Program Studi Desain Komunikasi Visual, Universitas Komputer Indonesia

\begin{abstract}
Abstrak. Abstrak, Ruang umum (public space) di perkotaan merupakan sebuah ruang yang dapat digunakan sebagai aktifitas oleh masyarakat umum, ruang public dapat berupa taman (park), kebun (garden), jalur hijau (greenways), pedestrian, jalan, trotoar, lapangan olah raga, plaza, dan semua ruang yang berada di luar bangunan. Ruang publik pada dasaranya dapt dibuat dengan terencana dan disadari dan didesain untuk kebutuhan masyarakat dan tidak terlepas dari dukungan pemerintah dalam upaya penyediaan fasilitas publik dalam sudut pandang tata kelola wilayah. Ruang publik perkotaan merupakan bagian dari produk arsitektur kota. Aktifitas pada ruang publik menjadi bagian dari perkembangan dalam proses penciptaan gaya hidup.
\end{abstract}

Kata Kunci : Environmental, Typography

\section{PENDAHULUAN}

Aktifitas manusia dalam kehidupan sehari - hari sangatlah beragam, mulai dari aktifitas rutin baik yang tercermin sebagai manusia pekerja, hingga pada kegiatan - kegiatan khusus bebagai pelengkap aktifitas manusia. Setiap bentuk kegiatan menusia tidak terlepas dari peranan tempat sebagai bagian dari perwujudan jati diri dan identitas, baik identitas yang dikhususkan secara personal sebagai diri sendiri, atau pun sebagai bentuk publikasi kelompok. Keberadaan manusia di suatu tempat dan senantiasa selalu berpindah dari satu tempat ke tempat lain mengantarkan pada terjadinya perubahan penampilan manusia itu sendiri. Pada saat bekerja manusia akan melakukan penyesuaian tampilan fisik mulai dari cara berpakaian, tutur kata, hingga pada bahasa tubuh, begitu pula manusia akan menyesuaikan keadaan saat berada pada ruang publik.

Masyarakat perkotaan menjadi suatu simbol dari kebudayaan massa (mass culture). Dalam kehidupannya baik disadari ataupun tidak, masyarakat 
perkotaan baik disadari ataupun tidak dapat menjadi obyek sekaligus subyek dalam tatanan perkembangan budaya. Simbol - simbol budaya industrialisasi dan pencitraan gaya hidup pada masyarakat perkotaan muncul seirirng dengan perkembangan kotan dan fasilitas serta sarana yang tersedia seperti, tempat hiburan, mall, bioskop, café, hingga pada ruang - ruang publik yang kerap dijadikan wahana menunjukan gaya hidup personal. Aktifitas pada ruang publik termasuk sarananya memungkinkan terjadinya pertukaran atau pertarungan ide gaya hidup.

Menurut Widaningsih,L (2002, p .2) "Dalam arsitektur, perkembangan budaya masyarakat selalu terkait dengan space dan places dimana perilaku budaya tersebut muncul dan terwujud dengan berbagai pola aktivitas pelakunya dalam sebuah seting ruang. Ruang dapat bermakna sebagai places apabila ruang tersebut dapat digunakan untuk kegiatan manusia, demikian halnya dengan ruang publik yang ada di perkotaan, dia bisa dikatakan sebagai "tempat" atau places apabila keberadaanya berfungsi bagi kegiatan masyarakat. Ruang publik yang dimaksud adalah ruang umum di perkotaan yang berada di luar bangunan, dapat digunakan publik dan memberi kesempatan untuk bermacam- macam kegiatan".

Arsitek Kota Bandung khususnya pada ruang - ruang publik mulai dikembangkan, salah satunya adalah monumental tipografi bertuliskan DAGO yang terletak di jalan Ir. H. Juanda Bandung. Dago merupakan sebutan yang popular untuk kawasan tersebut pada masyarakat Kota Bandung. Mulai akhir tahun 2008 kawasan sepanjang jalan Ir. H. Juanda menjadi sarana publik setiap hari minggu dengan sebutan "Car Free Day". Komposisi huruf yang dibuat secara monumental secara langsung dapat menjadi point of interest sekaligus menjadi memberikan dorongan hasrat dan selera untuk dapat melihat lebih dekat terlebih lagi pada daerah tersebut setiap berlangsungnya car free day terdapat beragam aktifitas dan sebagai ranah mempertunjukan diri pada masyarakat luas. 


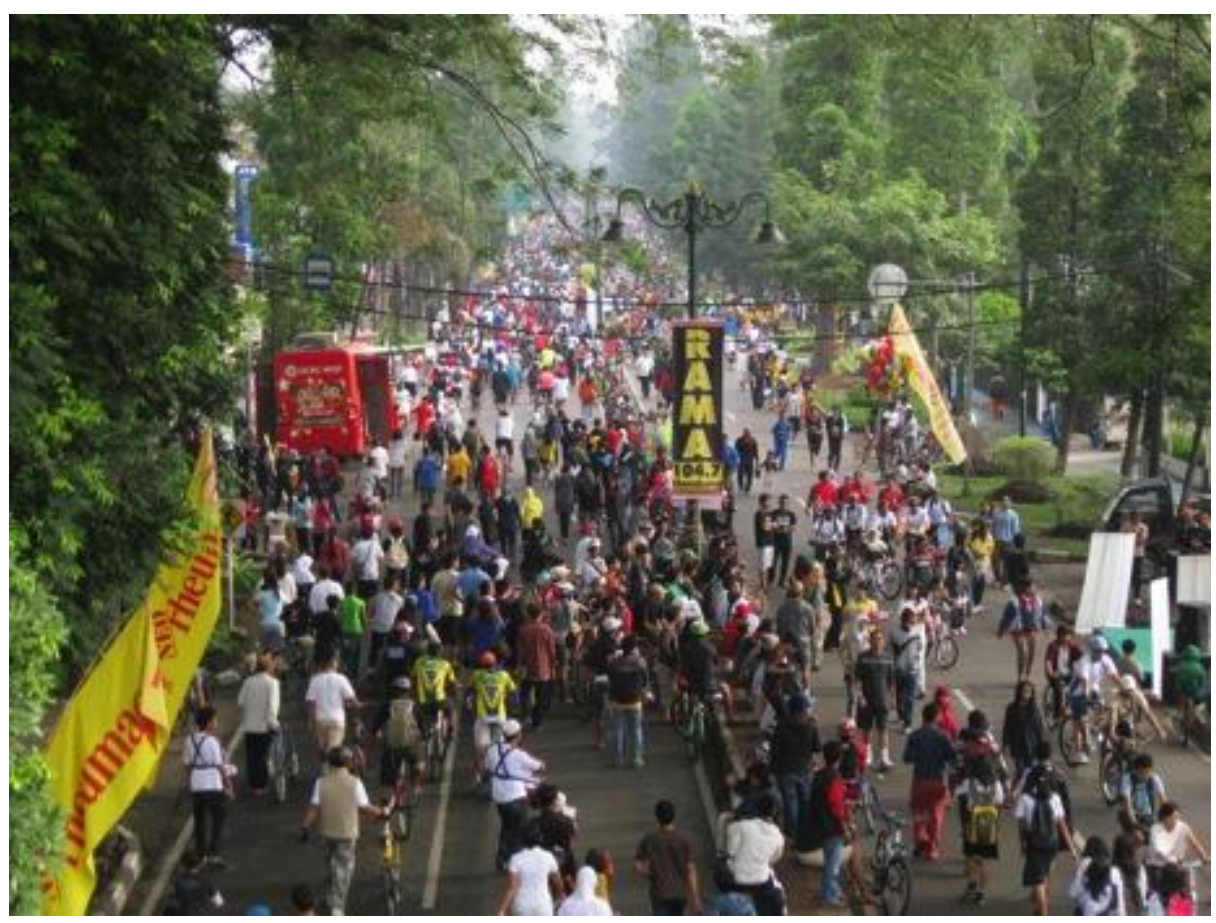

Gambar 1 : Aktifitas Car Free Day Dago

Sumber :http://luckydc.files.wordpress.com/2011/03/another-crowded-di-car-freeday-dago.jpg

\section{METODE DAN PEMBAHASAN}

\section{Tipografi}

Beberapa sumber menyebutkan bahwa tipografi adalah :

- Sebagai pelengkap dan alat bantu perkembangan teknologi cetak (print matter media)

- Tipografi sering disebut juga sebagai ilmu kajian tentang huruf

- Tipografi sering disebut juga sebagai seni memilih dan menata huruf, dengan pengaturan penyebarannya pada ruang - ruang yang tersedia, untuk menciptakan kesan khusus, sehingga akan menolong pembaca untuk mendapatkan kenyamanan pembaca semaksimal mungkin. Hill, $W$ (2005) "Typography can defined a art of selected right type printing in accordance with specific purpose; of so arranging the letter, distributing the space an controlling the type as to aid maximum the reader's". 
- Ada pula yang menyebutkan bahwa tipografi adalah merupakan elemen terpenting dalam desain grafis karena huruf merupakan sebuah bentuk yang universal untuk menghantarkan bentuk visual menjadi sebuah bentuk bahasa.

Seiring perkembang media dan teknologi, pengaplikasian tipografi hampir tidak ada batasan. Tipografi dapat diperankan sebagai coding dalam perkembangan teknologi komputer, serta tipografi dapat dijadikan identitas untuk sebuah ruang publik (Environment Typographic). Tipografi eksperimental kerap di identikan dengan tipografi yang radikal, yakni radikal dalam pemilihan bentuk, ukuran dan material serta proses pembuatan huruf termasuk komposisi penataan huruf. Jika yang dimaksud radikal dalam pesan, maka dadaisme berisi pesan yang memprovokasi, mengejutkan dan membangkitkan supaya sadar. Huruf dan tipografi adalah salah satu yang digunakan dalam dadaisme untuk mengekspresikan pesan tersebut. Begitu pula dengan tulisan DAGO yang ditempatkan pada sebuah ruang publik dapat sebagai bagian provokasi sekaligus identitas kawasan.

\section{Enviromental Typographic}

Environmental Typographic kerap dikaitkan dengan fungsi arsitektur, bentuk, ukuran dan material yang digunakan secara umum disesuaikan dengan elemen - elemen material pada bangunan dan dibuat dalam bentuk dimensional. Will Hill dalam bukunya The Complete Typografer (2005,p 56) "Possibility of three - dimensionality type is raised, incised or recessed. the condition may require illuminated signage, presenting a wide range of option for type to be lit from within, behind, above and below".

Secara umum tipografi memiliki fungsi sebagai : image, huruf, penyampai pesan dan lambang bunyi, dalam tipografi monumentalberperan bukan hanya untuk di baca dan dijadikan identitas sebuah ruang, tetapi 
peranannya dapat dirasakan langsung oleh penikmatnya. Relasi antara huruf dan manusia dalam ranah publik khususnya huruf yang diperankan dan dibuat monumental dapat meberikan dampak yang beragam. Huruf monumental pada ruang - ruang publik dapat terlibat dan bersentuhan langsung dengan manusia. Disadari atau tidak, huruf pada ruang publik dapat mengundang banyak orang untuk berada disekitarnya dan melakukan berbagai jenis aktifitas seperti halnya yang terjadi pada tulisan DAGO.

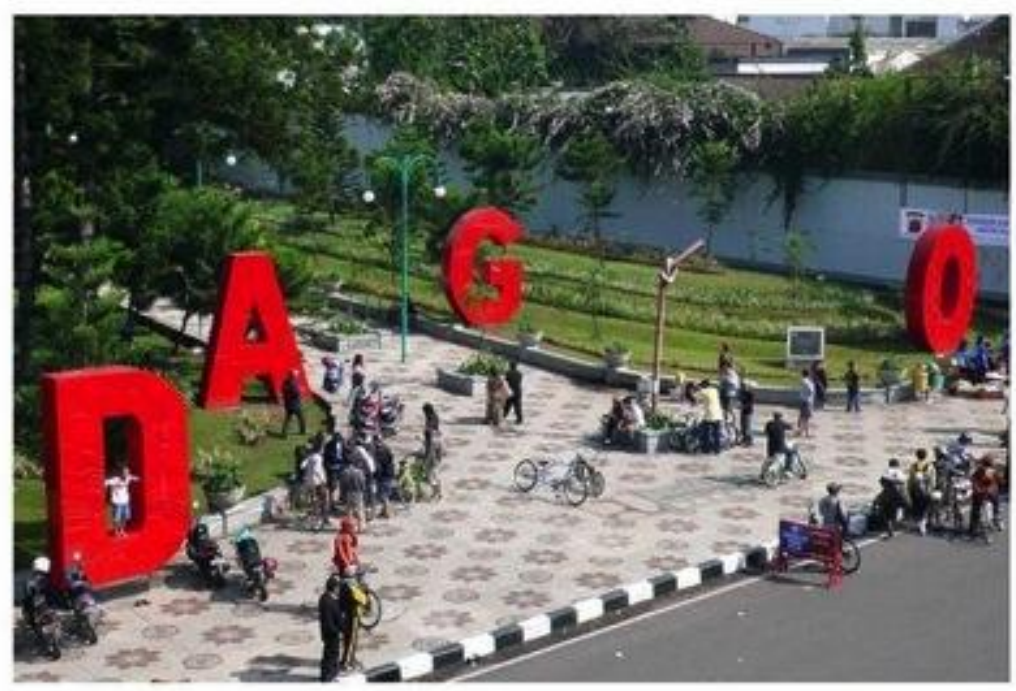

Gambar 2 : Monumental Tipografi DAGO

Sumber : http://media.tumblr.com/tumblr_11fyr9hRZR1qbti0u.jpg

\section{Ruang Publik (Public Space)}

Ruang umum (public space) di perkotaan merupakan sebuah ruang yang dapat digunakan sebagai aktifitas oleh masyarakat umum, ruang public dapat berupa taman (park), kebun (garden), jalur hijau (greenways), pedestrian, jalan, trotoar, lapangan olah raga, plaza, dan semua ruang yang berada di luar bangunan. Ruang publik pada dasaranya dapt dibuat dengan terencana dan disadari dan didesain untuk kebutuhan masyarakat dan tidak terlepas dari dukungan pemerintah dalam upaya penyediaan fasilitas publik dalam sudut pandang tata kelola wilayah. Ruang publik perkotaan merupakan bagian dari produk arsitektur kota. 
Ruang dan secara khusus ruang terbuka adalah fenomena yang sudah lama dikenal sejak zaman kuno. Kenyataan itu berarti bahwa ruang terbukaatau dalam istilah teknis lebih sering dipakai: open space - sudah lama diperhatikan walaupun dengan bermacam pendekatan. Oleh karena itu, arti open space dan secara khusus urban space (ruang perkotaan) tidak selalu dipahami berdasarkan pandangan yang sama. Masyarakat dengan latar belakang budaya yang berbeda akan memiliki pandangan yang berbeda terhadap makna ruang terbuka umum, sehingga pola penggunaan, aktivitas yang dilakukan serta berbagai prilaku budaya akan berbeda pula (Widaningsih,L; 2002).

Rustam Hakim dalam Widaningsih (1997), meninjau ruang terbuka dari kegiatannya yang menurutnya dapat dibagi ke dalam: 1) Ruang terbuka aktif, yaitu ruang terbuka yang mengundang unsur-unsur kegiatan di dalamnya seperti bermain, olahraga, upacara, bersantai, berjalan-jalan, berkomunikasi dan lain-lain. Ruang ini dapat berupa plaza, lapangan olah raga, area bermain, penghijauan di tepi sungai, dll., 2) Ruang terbuka pasif, yaitu ruang terbuka yang di dalamnya tidak mengandung kegiatan manusia seperti lahan hijau yang digunakan sebagai jarak terhadap rel kereta api, jalur hijau pembatas jalan bebas hambatan, dan lain-lain.

\section{Gaya Hidup(Life Style)}

Studi tentang kebudayaan senantiasa melibatkan telaah tentang aktivitas dan interaksi manusia, di samping tentang produk budaya (Subandy, I ; 1996). Aktivitas manusia dalam kehidupan sehari - hari tidak terlepas dari persoalan gaya hidup (life Style).

Gaya hidup atau life style merupakan ekspresi dari cara, pola, dan kebiasaan seseorang atau kelompok yang mencampuradukan nilai-nilai tertentu dari agama, sosial, dan kehidupan moral, yang dapat diamati dari penggunaan waktu, ruang/tempat, uang dan barang yang bersifat 
pragmatis. Misalnya bagaimana seseorang memilih pakaian yang bermerk, dimana dia berbelanja untuk kebutuhan hidupnya, bagiamana memilih makanan, dengan siapa berteman, apa yang dibaca, bagaimana memanfaatkan waktu luang. Gaya hidup dapat pula merupakan sebuah pola hidup yang dilakukan secara berulang - ulang aya sesuatu hal yang diulang. Dalam praktiknya sebuah gaya hidup tidak terlepas dari berbagai hal diantaranya modal, ruang sosial, identitas sosial serta habitus. Menurut Bourdieu (1996,p 14) "Habitus are these generative and unifying principles which retranslate the intrinsic and relation characteristics of a position into a unitary life style, that is unitary set of persons, goods, practices. like the positions of which they are the product, habitus are differentiated, but they are also differentiating".

Saussure mengemukakan bahwa berbicara mengenai gaya hidup merupakan persoalan 'difference', artinya suatu kelompok komunitas menganut gaya hidup tertentu, dan merupakan hasil perbandingan dengan kelompok komunitas lainnya.

Aktifitas manusia pada ruang - ruang public dapat menjadi arena pertarungan gaya hidup sekaligus sebagai media pertukaran gaya yang cesara langsung dapat berdampak terjadinya persilangan gaya. Seperti halnya pada kawasan Taman Cikapayang dimana kawasan tersebut sebagai sarana publik, terdapat beragam bentuk aktifitas manusia baik yang direncanakan ataupun tidak. Aktifitas yang direncanakan pada pelaksanaannya memanfaatkan sarana publik sebagai tempat (place) sebuah event. 


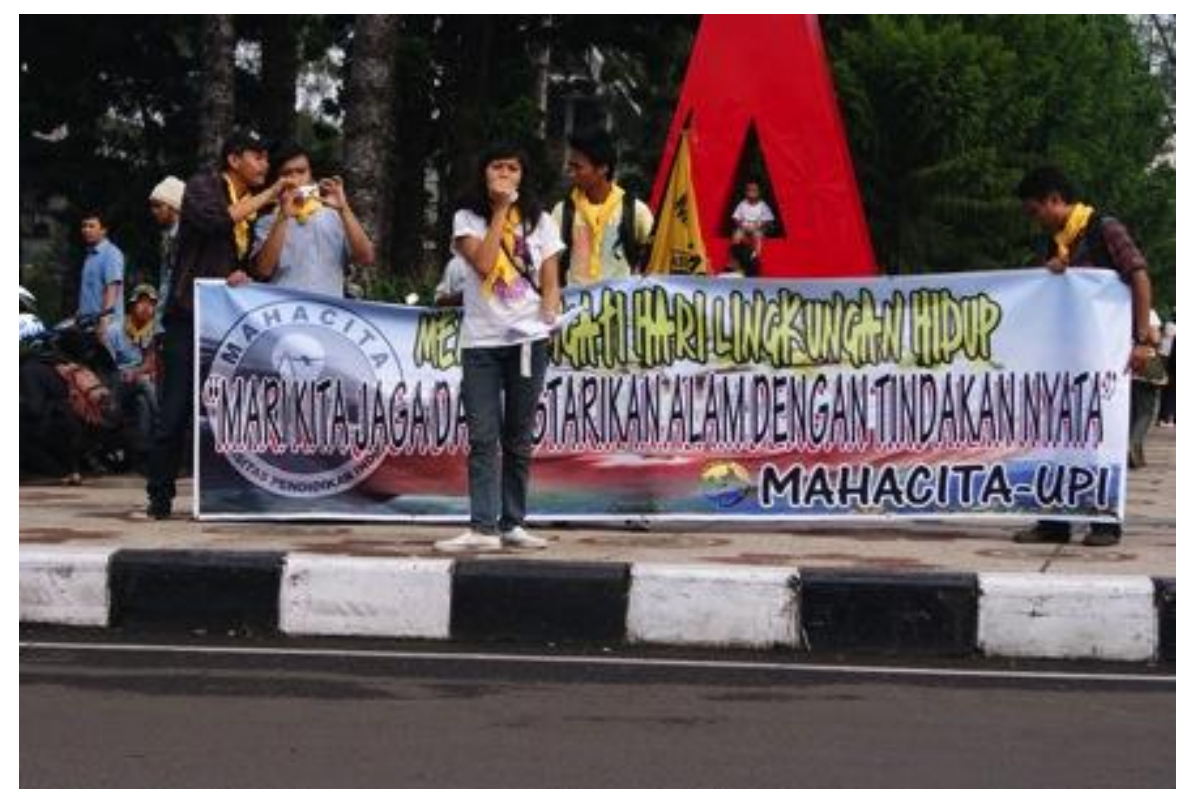

Gambar 3 : Sosialisasi Hari Lingkuan Hidup

Sumber : http://fotografibergerak.files.wordpress.com/2010/09/05-f-yosha-rorydago-car-free-day.jpg

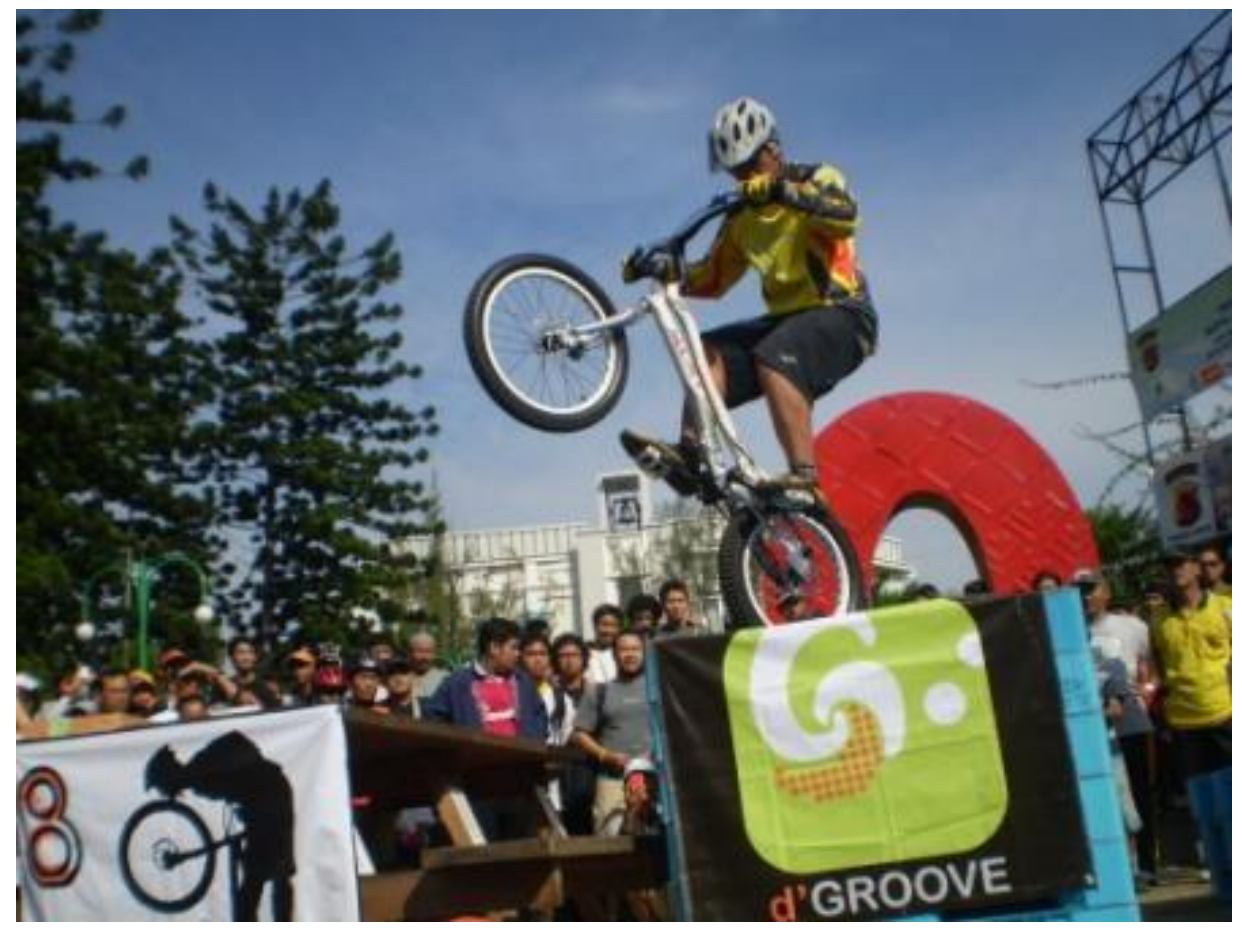

Gambar 4 : Extreme Games

Sumber :http://4.bp.blogspot.com/_j-E7TaMIGX8/SeCXr_ssgI/AAAAAAAAAHs/fKSJVMdYYBk/s1600/Car+Free+Day.JPG 


\section{Relasi Enviromental Typography, Public Space dan Gaya Hidup}

Gaya hidup selalu berkaitan dengan upaya membuat diri eksis dalam cara tertentu dan berbeda dengan yang lain, seperti Saussure mengemukakan bahwa berbicara mengenai gaya hidup merupakan persoalan 'difference', artinya suatu kelompok komunitas menganut gaya hidup tertentu, dan merupakan hasil perbandingan dengan kelompok komunitas lainnya. Taman Cikapayang yang dilengkapi dengan environmental typography menjadi salah satu ruang gaya hidup (space of life style) dimana keberadaan tulisan DAGO dapat memberikan dorongan kepada masyarakat luar untuk berinteraksi langsung antara tulisan (sign) dengan manusia.

\section{- Qualitas Space}

Keberadaan Taman Cikapayang secara geografis menjadi sangat strategis dimana lokasi dari taman cikapayang berada diantara ikon - ikon Kota Bandung lainnya seperti Institut Teknologi Bandung (ITB), Jembatan Layang Pasopati, Gasibu dan Factory Outlet yang berada di sepanjang jalan Ir. H. Juanda. Di sisi lain Jl. Ir. H. Juanda merupakan jalan protokol Kota Bandung. Kawasan Taman Cikapayang menjadi salah satu bagian wilayah yang termasuk dalam program Car Free Day. Dari beberapa pandangan diatas sudah dapat dipastikan bahwa dari sudut pandang geografis, taman cikapayang senantiasa dilalui oleh banyak orang baik yang menggunakan kendaraan maupun tidak.

Taman Cikapayang dalam sejarahnya adalah sebuah POM Bensin kini pencitraannya menjadi berubah setelah dirubah menjadi sebuah taman. Dengan adanya tulisan DAGO pada taman tersebut diyakini dapat menjadi :

- Drive : dorongan untuk masyarakat untuk dapat berhubungan langsung dengan obyek desain (environmental typography).

- Judgement : dapat menjadi pilihan untuk berbagai kegiatan, baik yang bersifat personal maupun kelompok. 
- Clasification : Taman Cikapayang dapat diklasifikasikan dan memiliki perbedaan yang signifikan di banding dengan taman taman sejenis di Kota Bandung.

- Internalisasi : Tulisan DAGO di Taman Cikapayang, dapat tertanam dalam pikiran manusia khususnya yang pernah datang ke Taman Cikapayang.

- Sence of Place :Tulisan DAGO dapat menjadi bagian yang dirasa cocok sebagai tempat ekspresi diri dengan bentuk pemanfaatan yang beragam.

\section{- Fungsi Ekologi}

Secara khusus Tulisan DAGO yang terletak di area Taman Cikapayang tidak dapat menjadi fungsi ekologi, namun area Taman Cikapayang dapat memberikan peranan langsung sebagai daerah hijau dan menjadi paru - paru kota. Keberadaan tulisan DAGO dapat memberikan efek psikologis secara langsung kepada masyarakat untuk dapat menghargai kawasan dan turut serta menjaga kawasan tersebut.

\section{- Fungsi Fisik}

- Tulisan DAGO yang berada di area Taman Cikapayang memiliki fungsi fisik sebagai identitas kawasan, dimana tulisan DAGO dengan ukuran yang besar dan tinggi dan berwarna merah dapat menjadi petunjuk keberadaan sebuah tempat serta dapat menjadi point of interest.

- Bagi beberapa instansi maupun kelompok, tulisan dago dapat dijadikan sebagai bagian dari setting panggung untuk sebuah acara ataupun menjadi background dokumentasi berupa ekspresi diri dalam bentuk foto maupun video.

- Dengan ukuran huruf yang relatif besar, tak jarang tulisan tersebut dapat dijadikan tempat berteduh.

\section{- Fungsi Sosial Budaya}

Tulisan DAGO dapat berperan mejadi media informasi sekaligus 
menjadi media interaksi antara manusia dengan produk desain secara langsung. Huruf secara fungsi dapat berperan sebagai penyampai pesan. Demikin pula dengan produk desain tulisan DAGO dapat menjadi pesan bagi masyarakat luas serta menjadi sebuah budaya baru bahwa sesuatu yang bersifat monumental tidak harus berupa gedung bersejarah, monumen, patung maupun benda - benda bersejarah lainnya. Huruf dengan perlakuan tertentu dapat dijadikan sebagai monumen.

Tulisan DAGO yang dibuat dengan ukuran yang besar, yang dibuat dengan tinggi rata - rata 3 (tiga) kali lebih besar dari tinggi manusia. Hal ini bertujuan agar dapat diperhatikan dari jauh dan dapat dijadikan sebagai media provokasi. Kawasan Cikapayang dengan tulisan DAGO didalamnya dapat menjadi kawasan tempat berinteraksi beragam aktifitas masyarakat kota Bandung, tanpa membedakan kelompok masyarakat tertentu.

\section{- Fungsi Estetika}

Tulisan DAGO dilihat dari fungsi estetika selain menjadi identitas kawasan dapat pula berperan sebagai bagian dari tata kota Bandung, dimana dalam sejarahnya daerah tersebut adalah sebuah POM Bensin. Keberadaan tulisan DAGO dapat menjadi differensiasi dengan taman - taman kota lainnya di kota Bandung, maupun di kawasan Indonesia.

Pada setiap huruf yang terdapat pada tulisan DAGO, terdapat unsur motif yang dapat memberikan nilai tambah sebagai fungsi estetika. Pada huruf $\mathbf{D}$ terdapat motif sendok dan garfu yang menjelaskan tentang DAGO sebagai kawasan kuliner. Pada huruf A terdapat motif menyerupai bentuk bunga, yang menggambarkan bahwa kawasan Dago merupakan daerah yang sejuk dimana kawasan Dago menjadi salah satu daerah resapan air di kota Bandung. 
Pada Huruf $\mathbf{G}$ terdapat motif yang menggambarkan wayang golek, hal ini menggambarkan tentang wayang golek adalah salah satu kekayaan budaya masyarakat Jawa Barat. Pada huruf $\mathbf{O}$ terdapat motif menyerupai anyaman yang menggambarkan bahwa kota Bandung merupakan kota kreatif, dimana di kota Bandung terdapat banyak pengerajin dan usaha kecil yang bergerak di bidang art and craft.

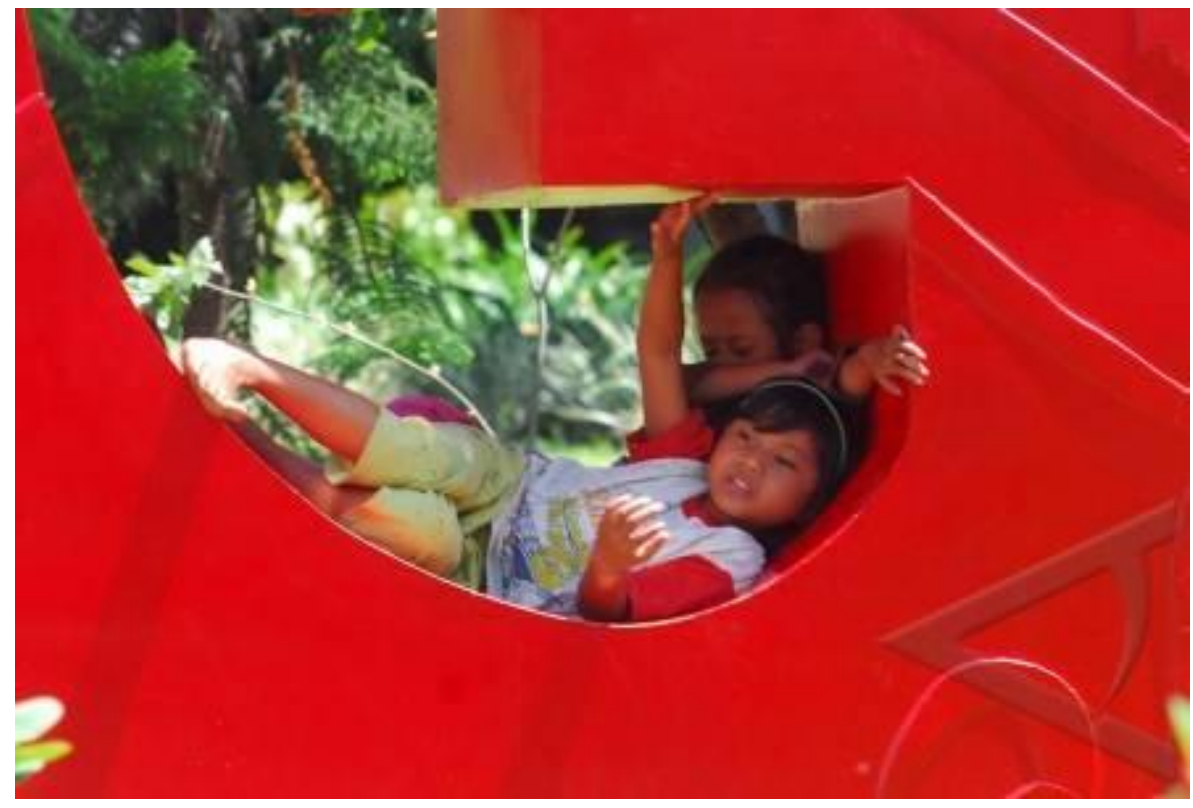

Gambar 5 : Pemanfaatan Ruang http://v-images2.antarafoto.com/gpo/1271933101/terpopuler\%20sepekan-anak-jalanan01.jpg

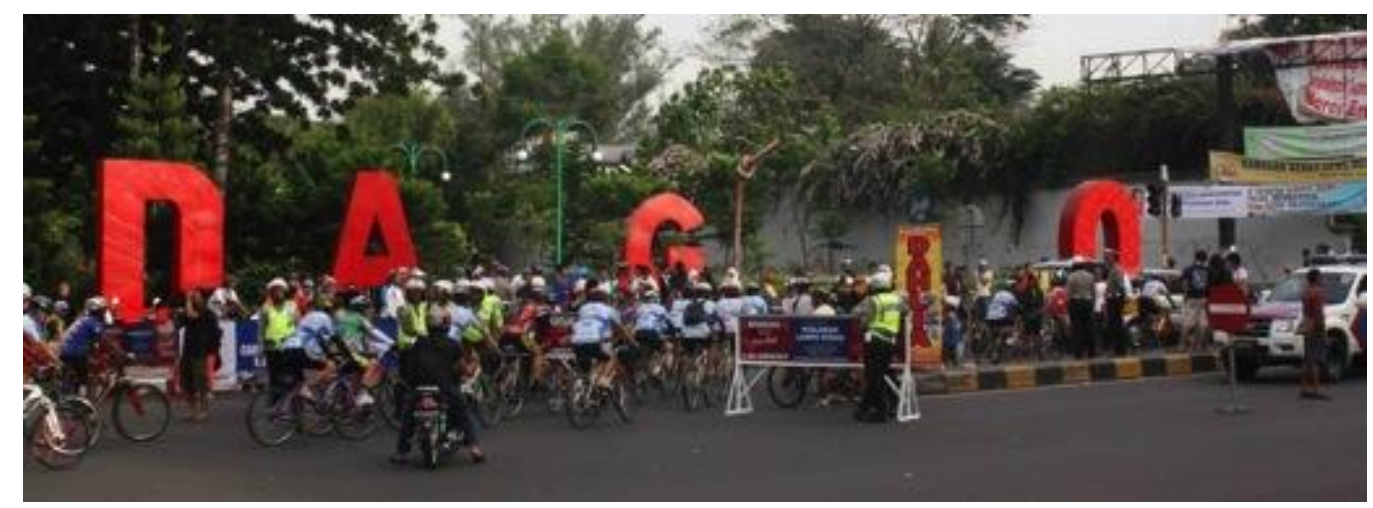

Gambar 6 : Car Free Day http://www.reportase.com/wp-content/uploads/2011/08/cfd-dago.jpg 


\section{- Tinjauan Teknik dan Material}

Dalam environmental typography, ukuran dan material menjadi bagian yang terpenting, pemilihan material yang baik dapat menunjang ketahanan produk desain untuk bertahan dalam jangka waktu yang lama mengingat biaya produksi yang tinggi. Ukuran disesuaikan dengan pesan yang ingin disampaikan, pada dasarnya dalam environmental typography, disain dibuat dengan ukuran yang besar, seperti halnya tulisan DAGO yang dibuat rata rata 3 (tiga) kali lebih besar dari tinggi manusia. Hal ini bertujuan agar dapat diperhatikan dari jauh dan dapat dijadikan sebagai media provokasi. Ukuran yang besar dapat pula menimbulkan rasa keingintahuan dari penikmatnya, mangingat bentuk - bentuk monumental khususnya huruf di Kota Bandung dapat dikatakan masih langka.

Besar dan kecilnya produk desain dapat memberikan dampak terhadap penikmatnya. Seperti yang dikatakan Saurure, different dapat menjadi salah satu bagian dalam gaya hidup. Peranan ukuran huruf bertuliskan DAGO menjadikan Kota Bandung memiliki nilai khas sekaligus memiliki perbedaan yang signifikan dibandingkan dengan kota - kota sekelas di Indonesia.

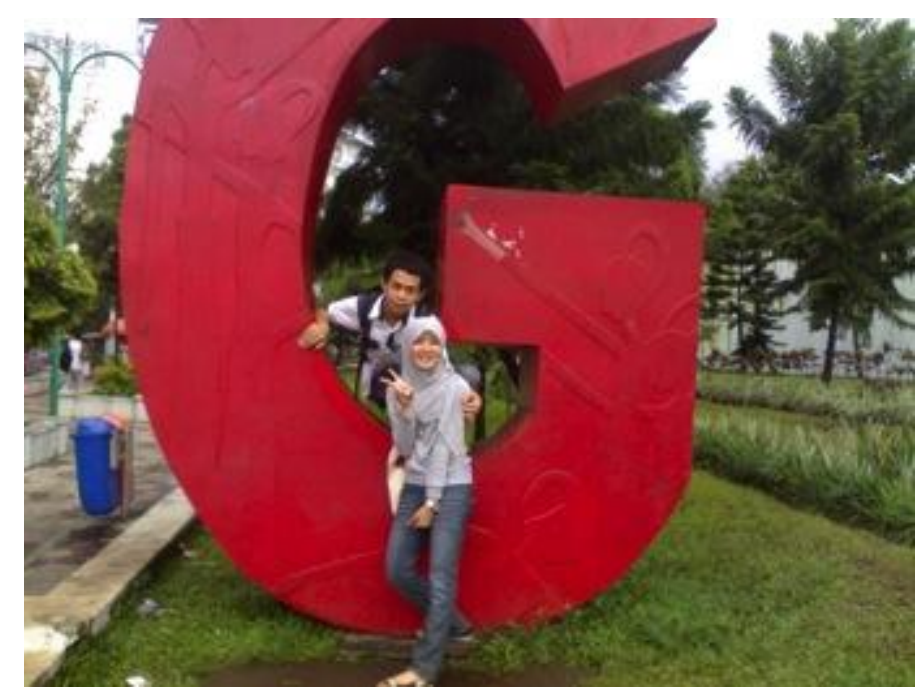

Gambar 7 : Bentuk Huruf O pada environmental typography 
Sumber : http://3.bp.blogspot.com/-

bJzurzWGUQo/TaatJMFsxMI/AAAAAAAAADE/tJG8wS8GcG4/s1600/vierG0 61.jpg

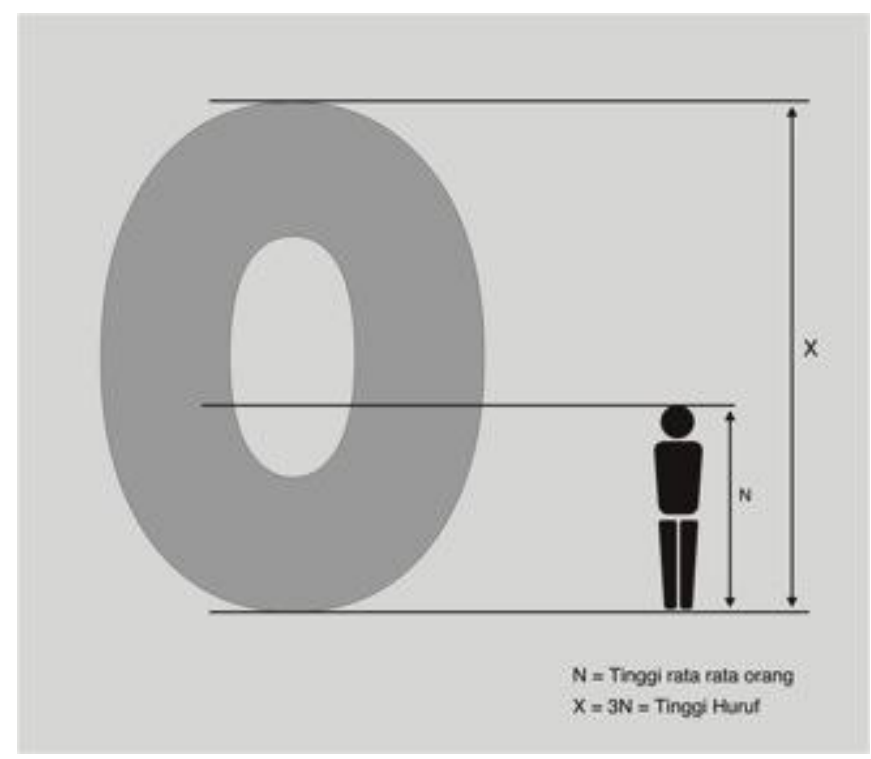

Gambar 8 : Perbadingan ukuran huruf dengan tinggi manusia

\section{KESIMPULAN}

Masyarakat perkotaan khususnya di Kota Bandung, selalu berusaha mewujudkan ekspresi emosinya lewat kegiatan - kegiatan yang dalam ukuran mereka dapat mewakili jiwa dan karakternya. Beragam bentuk kegiatan seperti penggalangan dana, olahraga, serta seni pertunjukan, merupakan salah satu contoh kegiatan yang sering digelar untuk memenuhi selera kaum muda kota dengan memanfaatkan fasilitas public sebagai temapt merealisasikannya. Tak jarang kegiatan Car Free Day di Kota Bandung menjadi wahana rekreasi keluarga sekaligus menjadi tempat pembelajaran gaya hidup sehat di Kota Bandung. Dibuktikan dengan banyaknya temuan yang berupa kegiatan - kegiatan yang berkaitan dengan pengolahan tubuh seperti bersepeda, jogging, senam pagi hingga pada promosi makanan atau minuman sehat dari beragam produsen.

Keberadaan environmental typography dapat dijadikan dapat dijadikan simbol perpaduan gaya hidup di Kota Bandung, selain menjadi point of interest dari sebuah kawasan. Bentuk kegiatan yang terus berkelanjutan di 
area Taman Cikapayang khususnya area yang terdapat tulisan dago menjadi personal history, bagi masyarakat yang pernah memanfaatkan fasilitas tersebut, dan akan memiliki daya tahan yang lama (durability) dalam benak masyarakat yang disebabkan oleh perbedaan yang signifikan dibandingkan dengan taman - taman yang lain di Kota Bandung dan atau di luar Kota Bandung.

Kualitas ruang Taman Cikapayang memberikan kontribusi yang signifikan bagi munculnya berbagai prilaku budaya serta menjadi daya tarik spacekarena letaknya yang strategis dalam skala kota sehingga dapat dijangkau oleh masyarakat Kota Bandung. Ada sisi positif dan negatifnya dari semua bentuk dinamika kota, namun kota tidak akan hidup tanpa aktivitas masyarakatnya, apapun bentuknya. Makin berkurangnya ruang publik di perkotaan di satu sisi, akan makin membatasi ruang hidup bagi masyarakat kota untuk berinteraksi, melakukan komunikasi, serta mengekspresikan gaya hidup.

Kebudayaan massa/pop yang merambah masyarakat perkotaaan merupakan bagian yang hampir tidak bisa dihindari. Masyarakat kota yang menjadi objek sekaligus subyek dalam proses perkembangan budaya tersebut, termasuk segala bentuk implikasinya telah menjadi bagian dari proses perkembangan kota. 


\section{DAFTAR PUSTAKA}

Allwood, J, (1985), Intercultural Communication, University of Göteborg, Dept of Linguistics.

Dair,Carl, (1988), Design With Type, Canada, University of Toronto Press

Hill, W, (2005), TheComplete Typographer : a manual for designing with type, PageOne,

Subandi I, (2005), Lifestyle Ecstasy, Yogyakarta, Jalasutra,

Smith, M, (2008), Visual Culture Studies, Singapore, SAGE

Supratman,D (2007), Physical Space, Social Space \& Habitus, University of Olso, Olso, 12 Oktober 2011, (ttp://www.sv.uio.no/iss/om/aktuelt/arrangementer/aubert/tidligere/dokumenter/au bert1995.pdf)

Widaningsih,L, (2002), Ruang Publik Kota Sebagai “Places” Dalam Mengembangkan Aktivitas Berkebudayaan Masyarakat Perkotaan, Bandung 